\title{
THE EFFECT OF CLIMATIC SHIFTS ON BIODIVERSITY OF PHYTOCENOSIS: LAKE ARAKHLEY (EASTERN SIBERIA, RUSSIA)
}

\author{
G. Ts. Tsybekmitova ${ }^{1}$, L. D. Radnaeva ${ }^{2}$, N. A. Tashlykova ${ }^{3}$, V. G. Shiretorova ${ }^{4}$, A. K. \\ Tulokhonov $^{5}$, B. B. Bazarova ${ }^{6}$ and M. O. Matveeva ${ }^{7}$ \\ ${ }^{1}$ The Institute of Natural Resources, Ecology and Cryology of the Siberian Branch of the Russian \\ Academy of Sciences, \\ 16, Nedorezova st., Chita, Russia; \\ Email: gazhit@bk.ru \\ ${ }^{2}$ Baikal Institute of Nature Management of the Siberian Branch of the Russian Academy of Sciences, \\ 6, Sakhyanovo st., Ulan-Ude, Russia; \\ Email: radld@mail.ru \\ ${ }^{3}$ The Institute of Natural Resources, Ecology and Cryology of the Siberian Branch of the Russian \\ Academy of Sciences, \\ 16, Nedorezova st., Chita, Russia; \\ Email: NatTash2005@yandex.ru \\ ${ }^{4}$ Baikal Institute of Nature Management of the Siberian Branch of the Russian Academy of Sciences, \\ 6, Sakhyanovo st., Ulan-Ude, Russia; \\ Email: vshiretorova@rambler.ru \\ ${ }^{5}$ Baikal Institute of Nature Management of the Siberian Branch of the Russian Academy of Sciences, \\ 6, Sakhyanovo st., Ulan-Ude, Russia; \\ Email: aktulohonov@binm.ru \\ ${ }^{6}$ The Institute of Natural Resources, Ecology and Cryology of the Siberian Branch of the Russian \\ Academy of Sciences, \\ 16, Nedorezova st., Chita, Russia; \\ Email: balgit@mail.ru \\ ${ }^{7}$ The Institute of Natural Resources, Ecology and Cryology of the Siberian Branch of the Russian \\ Academy of Sciences, \\ 16, Nedorezova st., Chita, Russia; \\ Email: marina_matveeva_94@inbox.ru
}

\begin{abstract}
Lake Arakhley is located within the Lake Baikal basin in Eastern Siberia, Russia. The area is characterized by continental subarctic climate with considerate diurnal temperature range, long cold dry winters and short hot summers with more precipitation occurring during the latter half of the summer. Climatic shifts in high water years and low water years result in morphometric changes in the lake and in the chemical and physical parameters of the ecosystem. During low water years, concentrations of ammonium nitrogen and nitrite nitrogen are decreased, whereas nitrate concentration increases. High water years feature average concentrations of ammonium ions 1.5-2 times higher than the values of recent dry years.

Redundancy analysis (RDA) of abiotic factors and biotic community indicated that the community structure shows the greatest correlation with physical and chemical parameters of water and biogenic elements (nitrites, ammonium, phosphates) along the first axis, and with the lake depth and transparency along the second axis.

Changes in abiotic factors induce functioning and formation of characteristic communities of the primary producers in the trophic structure of the ecosystem. During low water years, with increased level of autochthonous organic matter, Lindavia comta dominance is observed, while during high water years, with increased allochthonous organic matter Asterionella formosa appeared as dominant. Currently, during low water years, the hydrophytes community is monodominant and composed of Ceratophyllum demersum. Meanwhile, such species indicating eutrophic conditions as Myriophyllum sibiricum, Potamogeton pectinatus are found in the lake vegetation.
\end{abstract}

Keywords: Abiotic factors, phytoplankton, hydrophytes, Redundancy analysis (RDA)

\section{INTRODUCTION}


International Journal of Ecology \& Development. 2020. Vol. 35(3).

Monitoring and analysis of water ecosystems are crucial for creating early warning methods of further biological aftermath caused by anthropogenic activities. The composition and abundance of vegetation communities, as trophic producers, is typically determined by such abiotic factors as organic matter content (Koch 2001), wind and wave effects (Riis and Hawes 2003), temperature, water light intensity and nutrients (Bornette \& Puijalon 2011; Vinberg \& Lyakhnovich, 1965). These parameters are modified whether the lakes are filled up or dried up having a knock-on effect on the growth and development of vegetation communities (Hill et al., 1998; Bornette \& Puijalon 2011).

The coupled effect of climatic and anthropogenic factors leads to low biodiversity and degradation of the ecosystem function of natural complexes. It can hinder economic advancement and safety protection both nationally and internationally. In this regard, biological diversity research on different levels of organization and dynamics in Zabaikalsky Region can make an essential contribution to the studies on biosphere balance including that of water ecosystems.

Lake Arakhley belongs to the Lake Baikal basin designated a UNESCO World Heritage site (Figure 1).

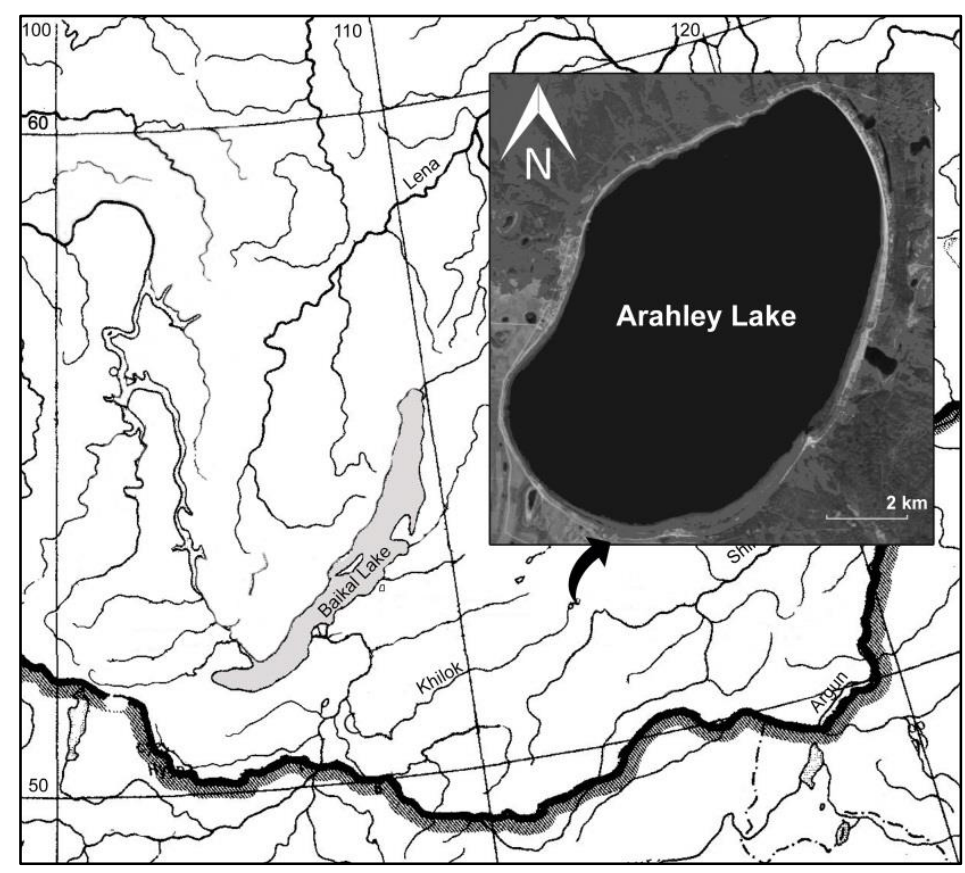

Figure 1. Schematic map of the Arakhley Lake

The Arakhley Lake is located in Eastern Siberia, Russia, in the south of the Vitim Plateau within the Beklemishev tectonic basin between the Yablonovy Mountains and the Osinovy Range. Geographical coordinates: $52^{\circ} 48^{\prime}-52^{\circ} 10^{\prime} \mathrm{N}, 112^{\circ} 45^{\prime}-113^{\circ} 04^{\prime} \mathrm{E}$. The surface elevation of the basin bottom is $940-930 \mathrm{~m}$ above sea level. Some characteristics of the Arakhley Lake are presented in Table 1.

Table 1: Characteristics of the Arakhley Lake (Obyazov et al., 2002)

\begin{tabular}{|c|c|}
\hline Characteristic & Arakhley \\
\hline Geographical coordinates & $\begin{array}{r}52^{\circ} 48^{\prime}-52^{\circ} 10^{\prime} \mathrm{N}, \\
112^{\circ} 45^{\prime}-113^{\circ} 04^{\prime} \mathrm{E}\end{array}$ \\
\hline Surface area, km² & 59.0 \\
\hline Water volume, $\mathrm{km}^{3}$ & 0.60 \\
\hline Length, km & 11.0 \\
\hline Max. width, km & 6.7 \\
\hline
\end{tabular}


International Journal of Ecology \& Development. 2020. Vol. 35(3).

\begin{tabular}{|l|c|}
\hline Average width, $\mathrm{km}$ & 5.3 \\
\hline Max. depth, $\mathrm{m}$ & 17.0 \\
\hline Average depth, $\mathrm{m}$ & 10.2 \\
\hline Shore length, $\mathrm{m}$ & 29.0 \\
\hline Catchment area, $\mathrm{km}^{2}$ & 256 \\
\hline Water exchange coefficient & 0.055 \\
\hline Trophic status & mesotrophic \\
\hline
\end{tabular}

The lake is situated some $100 \mathrm{~km}$ of the city of Chita, the capital of Zabaikalsky Region, and is used for recreational and fishery purposes. The aim of this study is to display changes in biodiversity of vegetation communities under climatic fluctuations.

\section{MATERIALS AND METHODS}

The materials presented in this research paper are based on the archives of the water ecosystems laboratory of the Institute of Natural Resources, Ecology and Cryology of the Siberian Branch of the Russian Academy of Sciences and the findings of the fieldwork conducted since October 2017 till October 2018.

The sampling, processing and analysis of hydrochemical materials were performed by the standard hydrochemical methods using spectrophotometer SPECOL-1300 (Manual, 1977). Physical and chemical parameters of water at sampling points were measured with AQWA-READER (Germany). The ion chromatography system ICS-1600 and a Profile Plus inductively coupled plasma atomic emission apectrometer was used to determine macro- and microcomponent composition of water.

The sampling and analysis of phytoplankton and hydrobotanical samples were conducted in accordance with conventional methods tailored for the environment of Zabaikalsky Region. (Kozhova, 1970; Katanskaya, 1981; Sadchikov, 2003; Bazarova, Namzalov, 2004; Tashlykova, 2009).

The standard spectrophotometric method (GOST 17.1.4.02-90) was used to determine the concentration of pigments. Along with chlorophyll a, the amounts of other pigments were determined: pheophytin $a$, carotenoids and chlorophylls $b$ and $c 1+c 2$. The physiological state of phytoplankton cells was estimated using the pigment ratio that represents the ratio of the optical densities of extracted pigments at long-wavelength maximum of chlorophyll to the carotenoids absorption spectrum (E430/E664).

Statistical and mathematical analyses of the findings were conducted using Microsoft Excel 2010 programs: Microsoft Excel and XLSTAT (Addinsoft, USA). The Redundancy analysis (RDA analysis) was performed to illustrate the correlation between the composition characteristics of the plankton and abiotic factors. For the purposes of the research, parameters were used as model variables: lake depth $(H)$, water transparency (TR), total dissolved solids (TDS), $\mathrm{pH}$, dissolved oxygen content $\left(\mathrm{O}_{2}\right)$, oxygenation $(\%)$, water temperature $(\mathrm{T})$, electrical conductivity (EC), oxidation-reduction potential (ORP), salinity (Sal), turbidity (Turb), ion content: nitrites $\left(\mathrm{NO}_{2}\right)$, nitrates $\left(\mathrm{NO}_{3}\right)$, ammonium $\left(\mathrm{NH}_{4}\right)$, phosphates $\left(\mathrm{PO}_{4}\right)$, permanganate oxidability index (PI), chemical oxygen demand (COD), chlorophyll a concentration (Xla), number of phytoplankton species ( $\mathrm{nph}$ ) and the main algal groups (Cyanobacteria ( $\mathrm{ncya}_{\mathrm{a}}$ ), Bacillariophyta (nbac), Chrysophyta (nchr), Charophyta (ncha), Chlorophyta (nchl), Euglenophyta (neug), Dinophyta (ndin)), total number of phytoplankton ( $\mathrm{Nph}$ ) and total biomass of phytoplankton (Bph), number and biomass of algal taxonomic groups (Cyanobacteria (Ncya, Bcya), Bacillariophyta (Nbac, Bbac), Chrysophyta (Nchr, 
International Journal of Ecology \& Development. 2020. Vol. 35(3).

Bchr), Charophyta (Ncha, Bcha), Chlorophyta (Nchl, Bchl), Euglenophyta (Neug, Beug), Dinophyta (Ndin, Bdin)), phytomass of higher water vegetation (Potamogeton perfoliatus L., P. pectinatus L., P. praelongus Wulf. (P. pr.), Myrrophyllum sibiricum Kom. (M. s.), Chara arcuatofolia Vilch. (C. a.), Ceratophyllum demersum L. (C. d.), Lemna trisulca L. (L. t.). Standartization of databases was conducted to reduce the dimensionality of the feature space (Shipunov et al., 2014).

\section{RESULTS}

\subsection{Physical and chemical indicators of the lake ecosystem}

Physical and chemical characteristics of the ecosystem are influenced by the location of the Arakhley Lake in the mountainous area and its continental subarctic climate under climatic fluctuations.

The Arakhley is a stagnant lake with the higher temperature of the surface layers than that of the bottom layers, reaching the highest values in August. Some physical and chemical indicators of water are presented in Figure 2. The lake water is slightly alkaline. In the central part, the indicators of $\mathrm{pH}$ level, oxygen content, oxygenation and water turbidity are insignificantly decreased from the surface to the bottom of the water column.

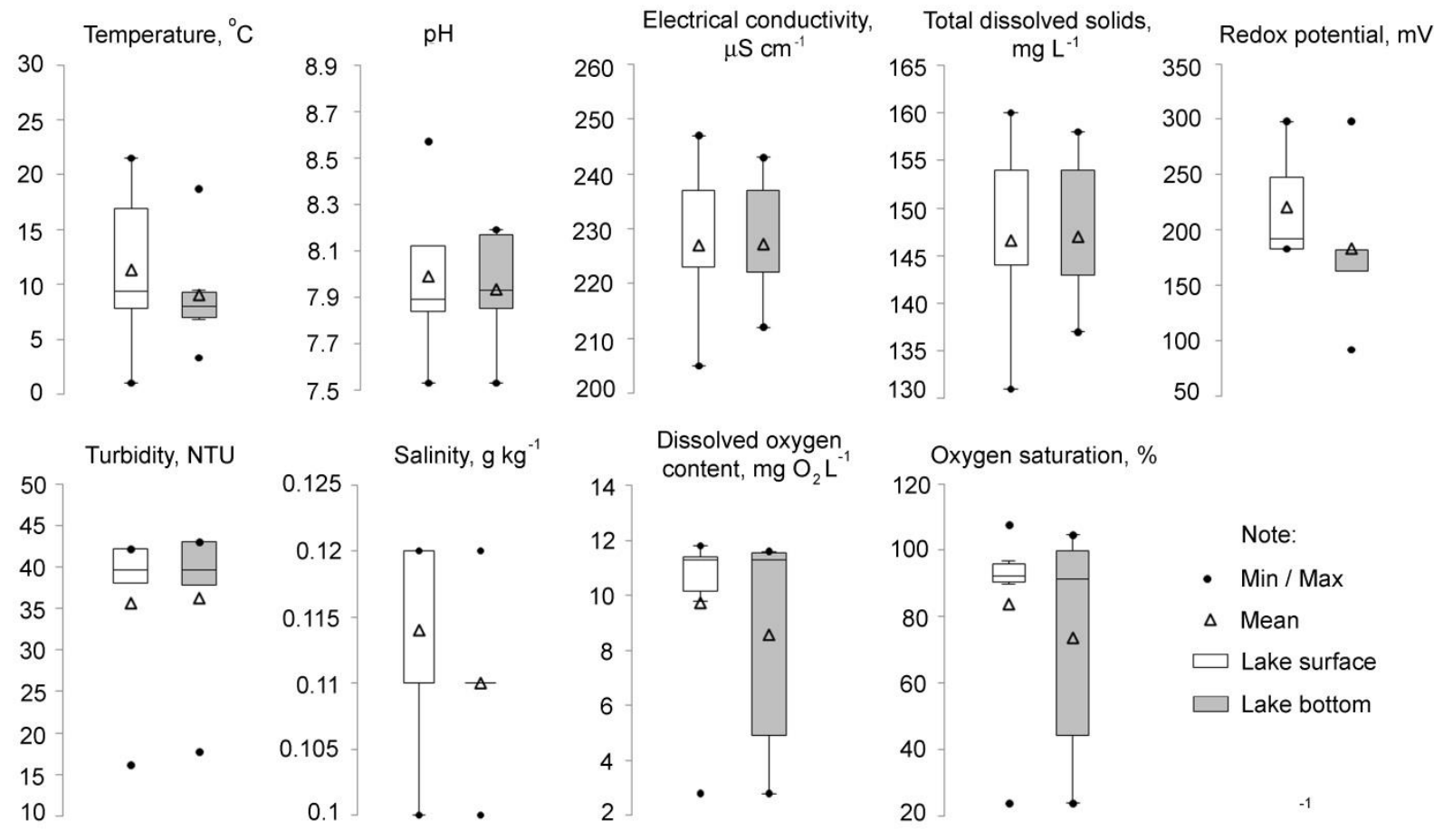

Figure 2. Physical and chemical indicators of the Lake Arahley (2017-2018)

With regard to total dissolved solids, the Arakhley Lake is a low-mineralized fresh lake. The chemical composition refers to the hydrocarbonate class with the sodium group (Table 2).

Table 2: Macro- and microelement composition of the waters of the Lake Arakhley $\left(\mathrm{mg} / \mathrm{dm}^{3}\right)$

\begin{tabular}{|c|c|c|c|}
\hline $\begin{array}{c}\text { Constituent } \\
\text { elements }\end{array}$ & Surface layer & Bottom layer & $\begin{array}{c}\text { MAC } \\
\text { [Standards.., } \\
2010]\end{array}$ \\
\hline $\mathrm{Cl}^{-}$ & $2.08 \pm 0.97$ & $2.23 \pm 1.10$ & 300 \\
\hline $\mathrm{SO}^{2-}$ & $1.15 \pm 0.24$ & $1.03 \pm 0.49$ & 100 \\
\hline
\end{tabular}


International Journal of Ecology \& Development. 2020. Vol. 35(3).

\begin{tabular}{|c|c|c|c|}
\hline $\mathrm{HCO}^{3-}$ & $136.64 \pm 53.22$ & $142.74 \pm 61.7$ & - \\
\hline $\mathrm{Na}^{+}$ & $15.46 \pm 8.01$ & $16.65 \pm 6.06$ & 120 \\
\hline $\mathrm{K}^{+}$ & $3.48 \pm 1.63$ & $3.6 \pm 0.95$ & 50 \\
\hline $\mathrm{Mg}^{2+}$ & $7.04 \pm 3.48$ & $7.01 \pm 2.68$ & 40 \\
\hline $\mathrm{Ca}^{2+}$ & $20.01 \pm 9.57$ & $21.01 \pm 5.32$ & 180 \\
\hline Mineralization & $186.4 \pm 62.8$ & $194.7 \pm 53.1$ & 1000 \\
\hline $\mathrm{Fe}$ & 0.005 & 0.019 & 0.1 \\
\hline $\mathrm{Zn}$ & 0.0007 & 0.0038 & 0.01 \\
\hline $\mathrm{Mn}$ & $<0.001$ & 0.865 & 0.01 \\
\hline $\mathrm{Pb}$ & $<0.001$ & 0.0017 & 0.006 \\
\hline $\mathrm{Ni}$ & $<0.001$ & $<0.001$ & 0.01 \\
\hline $\mathrm{Cd}$ & $<00001$ & $<0.0001$ & 0.005 \\
\hline $\mathrm{Cr}$ & $<0.001$ & $<0.001$ & 0.02 \\
\hline $\mathrm{Eh}$ & $77 \pm 8.2$ & $120 \pm 14.8$ & - \\
\hline
\end{tabular}

The contrastive analysis of macro- and microelement composition indicated that the surface layers are less mineralized than the bottom layers.

The findings on biogenic elements in the lake in the period of open water are shown in Table 3.

Table 3: The concentration of nutrients (nitrogen and phosphorus) and organic matter content $(\mathrm{OMC})$ in the central zone of the lake Arahley in the period of open water in $2017-2018(\mathrm{mg} / \mathrm{dm} 3)$

\begin{tabular}{|c|c|c|c|c|c|c|c|}
\hline \multirow{2}{*}{ Water horizon } & \multicolumn{3}{|c|}{ Nitrogen } & \multicolumn{2}{c|}{ Phosphorus } & \multicolumn{2}{c|}{ OMC } \\
\cline { 2 - 8 } & $\mathrm{NO}^{2-}$ & $\mathrm{NO}^{3-}$ & $\mathrm{NH}_{4}^{+}$ & $\mathrm{PO}_{4}^{3-}$ & $P_{\text {total }}$ & $P O$ & $\mathrm{COD}$ \\
\hline \multirow{2}{*}{ Surface layer } & $0.001 \pm$ & $0.51 \pm$ & $0.004 \pm$ & $0.014 \pm$ & $0.031 \pm$ & $4.89 \pm$ & $10.28 \pm$ \\
& 0.0001 & 0.048 & 0.0004 & 0.0013 & 0.0011 & 0.97 & 3.23 \\
\hline \multirow{2}{*}{ Bottom layer } & $0.006 \pm$ & $0.56 \pm$ & $0.002 \pm$ & $0.023 \pm$ & $0.038 \pm$ & $6.1 \pm$ & $12.43 \pm$ \\
& 0.0007 & 0.054 & 0.0002 & 0.0022 & 0.0022 & 6.2 & 4.1 \\
\hline
\end{tabular}

Note: PO - permanganate oxidability; COD - chemical oxygen demand

In the period of open water, the nitrate form of nitrogen was dominant. The nitrites and ammonium ions were minimal. The concentration of phosphorus was increased in the bottom layers as compared to the surface layers. As to the PO/COD ratio, organic matter is of autochtonous origin. The average content of organic carbon ranges from $3.86 \pm 0.21 \mathrm{mg} / \mathrm{dm}^{3}$ (surface) to $4.66 \pm 0.35 \mathrm{mg} / \mathrm{dm}^{3}$ (bottom).

\subsection{The composition of the primary producers of organic matter}

A total of 39 taxa at the rank below genus were detected in the phytoplankton of the central Lake Arakhley during the study from 2017 to 2018 . The most diverse group was represented by diatoms, green algae and golden algae with $85.7 \%$ of total identified taxa. Among the most frequent species are the following: Lindavia comta (Kützing) Nakov, Gullory, Julius, Theriot \& Alverson, Fragilaria crotonensis Kitton, F. radians (Kützing) D.M.Williams \& Round, Ulnaria ulna (Nitzsch) Compère in Jahn et al., Cocconeis placentula Ehrenberg, Nitzschia graciliformis Lange-Bertalot \& Simonsen, Chrysococcus rufescens Klebs, Dinobryon cylindricum O.E. Imhof, D. divergens O.E. Imhof, D. sertularia O.E.Imhof, Kephyrion spirale (Lackey) Conrad, Oocystis marssonii Lemmermann.

Quantitative development of algae during springtime was insignificant with predominance of small-size Chrysophyta. The number varied from 24.96 to $188.48 \times 10^{3}$ cells $/ \mathrm{L}$ with the average value of $73.5 \pm 54.1 \times 10^{3}$ cells $/ \mathrm{L}$. The content of biomass ranged from 46.8 to $85.96 \mathrm{mg} / \mathrm{m}^{3}$ (the average value $64.77 \pm 19.8 \mathrm{mg} / \mathrm{m}^{3}$ ). The composition of algocenoses was determined by Chrysophyta with $10-75 \%$ of total taxa and $30-92 \%$ of overall biomass and Bacillariophyta with $20-85 \%$ of total taxa and $10-60 \%$ of 
International Journal of Ecology \& Development. 2020. Vol. 35(3).

overall biomass. In the summer, the total number of algae and overall biomass were increased by an order of magnitude due to massive growth of large forms of diatoms in the water column with 341.28$3733.4 \times 10^{3} \mathrm{cells} / \mathrm{L}$ (the average value $1058.52 \times 10^{3} \mathrm{cells} / \mathrm{L}$ ), the content of biomass $-422.56-1253.63$ $\mathrm{mg} / \mathrm{m}^{3}$ (the average number $887.72 \pm 424.33 \mathrm{mg} / \mathrm{m}^{3}$ ). Bacillariophyta prevailed in the phytoplankton with $60-80 \%$ of total taxa and $50-95 \%$ of overall biomass. The winter season was similarly marked by the Bacillariophyta predominance in the algocenosis with 34.2 to $226,1 \times 10^{3}$ cells/L $\left(139.46 \pm 89.03 \times 10^{3}\right.$ cells $/ \mathrm{L}$ ), the content of biomass -13.24 to $272.93 \mathrm{mg} / \mathrm{m}^{3}$ (the average number $171.31 \pm 104.7 \mathrm{mg} / \mathrm{m}^{3}$ ).

Pigment indicators of the phytoplankton in the central part of the Arakhley Lake in the period of open water in 2017-2018 are presented in Table 4.

Table 3: Pigment indicators of the phytoplankton of the Arakhley Lake $\left(\mathrm{mg} / \mathrm{dm}^{3}\right)$

\begin{tabular}{|c|c|c|c|}
\hline \multirow{2}{*}{ Indicators } & \multicolumn{3}{|c|}{ Period of study } \\
\cline { 2 - 4 } & May-June & August & October \\
\hline $\mathrm{C}_{\mathrm{xa}}$ & $0.50 \pm 0.21$ & $0.39 \pm 0.14$ & $1.87 \pm 0.82$ \\
\hline $\mathrm{Cb}$ & $0.36 \pm 0.32$ & $2.90 \pm 1.04$ & 0 \\
\hline $\mathrm{C} \mathrm{c} 1+\mathrm{c} 2$ & $0.44 \pm 0.33$ & $0.37 \pm 0.06$ & $0.20 \pm 0.09$ \\
\hline $\mathrm{Ck}_{\mathrm{y}}$ & $0.28 \pm 0.12$ & $0.24 \pm 0.12$ & $0.79 \pm 0.02$ \\
\hline $\mathrm{I}$ & $1.7-5.7$ & $1.7-3.0$ & $2.1-2.3$ \\
& $3.5 \pm 1.1$ & $2.5 \pm 0.31$ & $2.2 \pm 0.04$ \\
\hline
\end{tabular}

Notes: $\mathrm{Cxa}$ - content of chlorophyll a as adjusted for the presence of pheophytin; $\mathrm{Cb}$ - content of chlorophyll b; $\mathrm{Ck}$ - content of carotenoids; $\mathrm{C} c 1+\mathrm{c} 2$ - content of chlorofylls $\mathrm{c} 1$ and $\mathrm{c} 2 ; \mathrm{I}-$ pigment index (E430/E664).

The content of chlorophyll a varied from 0.39 to 1.87 with the average value of $0.95 \pm 0.08 \mu \mathrm{g} / \mathrm{dm} 3$ in the period of open water. The highest percentage of chlorophyll a was detected in October, the lowest - in August. The absence of the descendants of chlorophyll-pheophytin indicates high activity of organisms participating in photosynthesis. The average values of pigment index vary from 2 to 3.5 . The correlation ration carotenoids/chlorophyll has low value of -0.46 .

In 2018, the higher water vegetation in the Arakhley was observed at its maximum depth of 4.0$4.5 \mathrm{~m}$ due to the shift of the littoral zone during drought period. The zones of $4.0 \mathrm{~m}$ depth in 2018 are overlapped by those of $6.0 \mathrm{~m}$ depth in 1998. The composition of hydrophytes community appears to be monodominant. Ceratophyllum demersum A. Gray are dominant components in the lake. Such species indicating eutrophic conditions as Myriophyllum sibiricum Kom., Potamogeton pectinatus L. are found in the lake vegetation of the nearshore zone.

\subsection{Phytoplankton composition in correlation with abiotic environmental factors}

RDA singled out two factors most responsible for the changes in the phytoplankton of the central zone of $94.92 \%$ (Fig. 3). The percentage of other parameters is insignificant and thus those were not considered. 
International Journal of Ecology \& Development. 2020. Vol. 35(3).

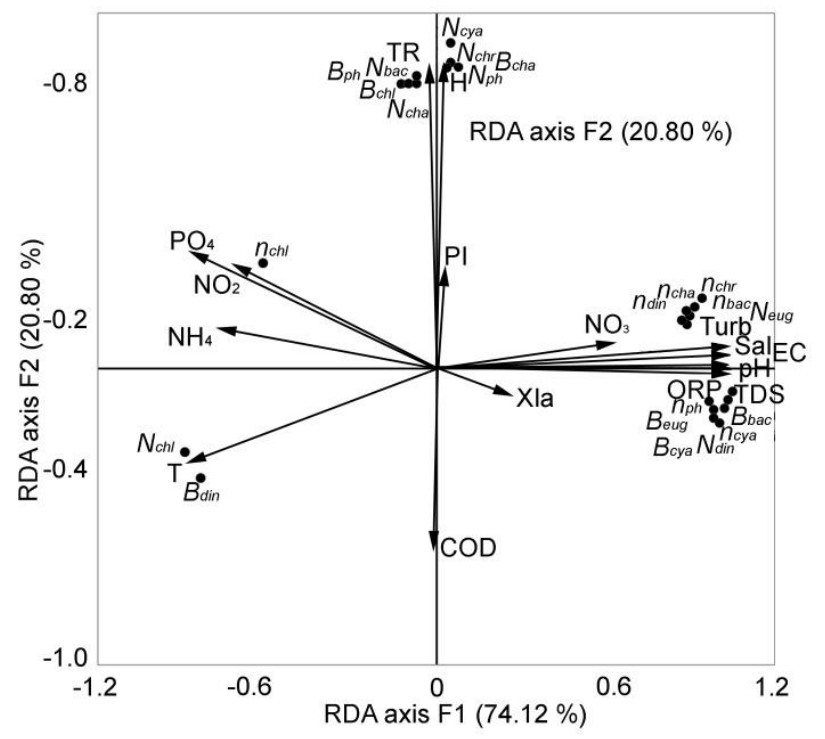

Figure 3. RDA analysis of phytoplankton composition and abiotic factors within the first two major factors in the central zone of the Arakhley Lake in 2017-2018

The number of Chlorophyta and biomass of Dinophyta showed clear negative correlation, while the number and biomass of Euglenophyta, the number of Dinophyta, and biomass of Cyanobacteria and Bacillariophyta as well as the number of taxa of Cyanobacteria, Bacillariophyta, Chrysophyta and Chlorophyta positively correlated with the first major factor (RDA axis 1), which explained a $74.12 \%$ variability of the community. The second major factor (RDA axis 2 ) explained a $20.80 \%$ variability of the pelagial communities. The number of microalgae and groups of Chlorophyta and Charophyta, as well as Cyanobacteria and Bacillariophyta demonstrated positive correlation with RDA axis 2. The most meaningful effect on the biocenosis is made by the abiotic factors of physical and chemical parameters of water (TDS, pH, EC, ORP, Turb and Sal) positively correlated with RDA axis 1 and biogenic elements (nitrites, ammonium, phosphates) negatively correlated with RDA axis 1. Depth and transparency showed a positive correlation with RDA axis 2.

\section{DISCUSSION AND CONCLUSION}

Lake Arakhley is located within the Lake Baikal basin in Eastern Siberia, Russia. Physiographically, it lies in the south of the Vitim Plateau within the Beklemishev tectonic basin (IvanArakhley Lakes..., 2013). The area is characterized by continental subarctic climate with considerate diurnal temperature range, long cold dry winters and short hot summers with more precipitation occurring during the latter half of the summer.

Climatic shifts in high water years and low water years result in morphometric changes in the lake and in the chemical and physical parameters of the ecosystem. Recently, the level of Lake Arakhley was lowered approximately by $2 \mathrm{~m}$. Dry climate and lowering water level lead to increasing mineralization of lakes under the conditions of water concentration by evaporating during summer and freeze concentration process in winter (Zamana \& Borzenko, 2010; Namsaraev \& Barkhutova, 2011). In contrast with lakes in arid zones, in the Arakhley Lake, there are not any remarkable stable changes observed in 
International Journal of Ecology \& Development. 2020. Vol. 35(3).

water mineralization (Table 2). This phenomenon the author (Shishkin, 1972, 1973) explains by ground waters actively feeding into lakes.

Specific meteorological conditions contribute to the thermic regime of the Arakhley Lake during the period of open water (Obyazov, 2011). The sun heating of the lake water starts from under ice in the mid-April and finishes in its surface layer in the mid-June - the early August. (Ivan-Arakhley Lakes..., 2013). In the summertime, mass exchange between the water reservoir, atmosphere and bottom sediments results in stratified thermal conditions with temperature gradient of a little under $10^{\circ} \mathrm{C}$ between surface and bottom layers (Fig. 2). Stratification influences availability of biogenic substances and biodiversity of hydrobionts (Moss et al., 1997; Rodrigo et al., 2001; Dawidowicz et al., 2002; Nagy et al., 2003; Padisak \& Reynolds, 2003; Gorbunov, 2007).

The analysis of year-to-year variations of biogenic elements and organic matter (Fig. 4) showed that the ammonium and nitrite nitrogen content has been decreasing since 2011 up to the present moment while the nitrates percentage has been growing. During high water years, the average values of ammonium ions content are higher as compared to those of the recent dry years (Ivan-Arakhley Lakes..., 2013). The concentration of phosphates and phosphorus has increased since 2013 to 2018.
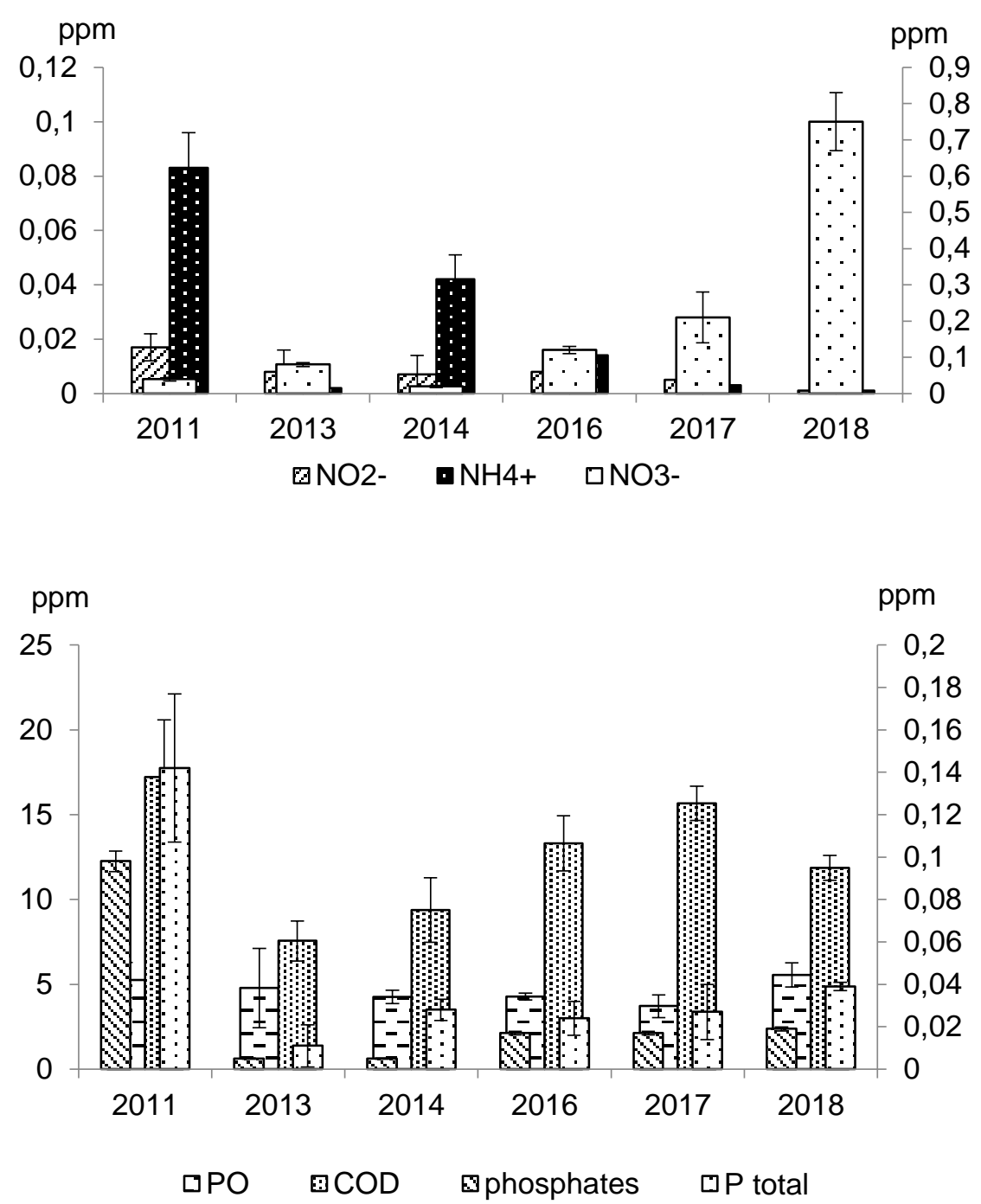

Figure 4. Annual dynamics of biogenic elements, easily oxidable organic matter, and organic matter resistant to oxidation in the Arakhley Lake $\left(\mathrm{mg} / \mathrm{dm}^{3}\right)$ 
International Journal of Ecology \& Development. 2020. Vol. 35(3).

At the present time, compared to the data obtained in the early 2000s, inorganic phosphorus content has become prevalent (the average ratio of Pmin/Ptotal was $0.22 \pm 0.04 \mathrm{mg} / \mathrm{l}$ ) due to the decreasing content of iron that removed inorganic phosphorus through chemical precipitation and contributed to the increase of organic phosphorus. During high water years, the average value of iron content was 0.10 to $0.35 \mathrm{mg} / \mathrm{l}$ (Usmanov \& Zhilin, 2002) while in low water years its percentage was reduced almost as twice as compared to the high water years (Table 3 ).

The variations of level regime of the water body cause its annual changes in phytoplankton composition. Retrospective analysis of the dominant phytoplankton complex in the Arakhley for the period of more than 50 years (1966-2018) indicates that low water years feature prevalent Cyclotella comta Kützing (currently - L. comta (Guiry, Guiry, 2017)), high water years - Asterionella formosa Hassall (Morozova, Shishkin, 1973). Thus, in 1966-1969, algocenosis of the lake was represented by abundant C. comta (Morozova, 1975; Morozova, Shishkin, 1973), in 1970-1971 - A. formosa (Morozova \& Shishkin, 1973; Morozova, 1981), in 1990-1995 - A. formosa (Ogly, 1993, 1995), in 2008-2009 Puncticulata radiosa (Kützing) H. Hakansson (currently - L. comta (Guiry, Guiry, 2017)) (Ivan-Arakhley Lakes..., 2013), in 2017-2018 - L. comta (Tashlykova, 2018).

The mentioned distribution of the dominant species corresponds with alternate phases of the hydrological cycle in the lake: in 1962, the lake level reached its maximum and started decreasing during the next year; in 1967-1968, the level drop stopped and started growing up to 1972. The next low water phase continued to 1980, with further level increasing within 4-6 years. Up to 1990-1991, the variations of the lake level were marked by rather high values. In the early 1990s, the level started dropping until 2008 when its value was close to the absolute minimum (Obyazov, 2011).

The data collected on the structure of the phytoplankton of the Arakhley Lake can be compared to those for the water bodies of Siberia and some other lakes of the European part of Russia (Vislyanskaya, 1982; Kasperovichene \& Karosene, 2005; Zarubina et al., 2005; Pomazkina et al., 2010; Chekryzheva \& Kalinkina, 2016; Rusanovskaya et al., 2017). Similar findings on the significance of abiotic factors were obtained during laboratory analyses and stationary research in other water bodies (Trifonova, 1990; Abakumov \& Izrailsky, 2012; Devyatkin et al., 2012; Dudakova et al., 2015; Datsenko et al., 2017;). The condition of phytoplankton communities reflects the reaction of the species to such environmental changes as mixing, water heating, catchment, as well as physical and chemical properties causing changes in algo- and zoocenoses (Trifonova \& Makartseva, 2006).

The highest concentration of chlorophyll a, detected in October, is correlated with seasonal transparency (Table 5). The more transparent is the water, the higher is the content of phytoplankton and chlorophyll a (Bul'ion, 1993). The value of the pigment index varies from 1 to 2 during algal bloom when respiration is insignificant, while in the late summer, with intense respiration the pigment index reaches values of 3-6 (Odum, 1975; Izmetieva et al., 1990; Mineeva, 1995; Sigareva, 1993; Markager et al., 1999). This correlation holds for the Arakhley Lake as well. The obtained pigment index data with value of higher than 3 in the bottom layers illustrate dominance of heterotrophic metabolism and low photosynthetic activity of the plankton. In most low water years, the PO/COD ratio indicates the autochthonous origin of the organic matter (Fig. 4).

Since 1967 till 2018, maximum depth of the lake vegetation was reduced from $11.0 \mathrm{~m}$ to $4.0 \mathrm{~m}$. In 1998, maximum vegetation depth was detected at the $6.0 \mathrm{~m}$ isobath. Additionally, the area of vegetation of Nitella opaca L. and Fontinais sp. has significantly decreased with final extinction of these species from 
International Journal of Ecology \& Development. 2020. Vol. 35(3).

the lake vegetation in 2000. Chara sp. and $N$. opaca that had been dominant since 1967 were replaced by N. opaca и Ceratophyllum demersum in 1974. In 1998-2000, C. demersum and Lemna trisulca prevailed within the community, while in 2018 , those were suppressed by $C$. demersum.

The findings on the composition of lake vegetation compared to the literature data demonstrate similar trends in both Russia's water bodies (Ladoga Lake..., 1992; Raspopov et al., 2002; Trifonova et al., 2006), and international ones (Sand-Jensen \& Borum, 1991, Kowalczewski \& Ozimek, 1993; Zhu et al., 2006; Scheffer \& Van, 2007; Rip et al., 2007; Lambert \& Davy, 2011).

In fact, the vegetation communities of lakes are mainly formed under abiotic factors (Vinberg \& Lyakhnovich, 1965; Hill et al., 1998; Bornette \& Puijalon 2011). This, in the Arakhley Lake, the most important abiotic factors are the concentrations of nitrites, oxygen, and chlorophyll a. These factors indirectly derive from phytomass of higher water vegetation that serves as the secondary sort of organic matter for other hydrobionts, in particular phytoplankton, and also, hinders mass vegetation of other algal groups by oxygen supersaturation (algicidal properties of macrophytes) (Khaliullina \& Yakovlev, 2015).

Successional high water years and low water years under continental subarctic climate result in cyclic changes of the morphometric lake characteristics and physical and chemical parameters of the ecosystem.

RDA analysis of the correlation between abiotic factors and biocenosis indicated that such physical and chemical parameters of water (TDS, pH, EC, ORP, Turb and Sal), biogenic elements (nitrites, ammonium, phosphates), and depth and transparency are the most influential abiotic factors

In low water years, autochthonous organic matter brings Lindavia comta to dominance, while during high water years, with increased allochthonous organic matter Asterionella formosa appeared as dominant.

The composition of hydrophyte communities is monodominant and represented by Ceratophyllum demersum. The lake vegetation features such species indicating eutrophic conditions as Myriophyllum sibiricum, Potamogeton pectinatus.

\section{Acknowledgements}

The work was carried out under the FNI program (project IX.137.1) and financial support of the Russian Foundation for Basic Research 17-29-05085 ofi_m. We would like to thank Researcher BIP SB RAS I.A. Pavlov for assistance in sampling.

\section{REFERENCES}

Abakumov, A.I., Israel, Yu.G., 2012, The influence of environmental conditions on the distribution of phytoplankton in the reservoir. Mat biol. and bioinform. 7(1), 274-283.

Bazarova, B.B., Namzalov, B.B., 2004, Spatial structure of vegetation of Lake Arakhley (Eastern Transbaikalia). Bulletin of Buryat University. Series 2: Biology. 6, 13-23.

Bornette, G., Puijalon, S., 2011, Response of aquatic plants to abiotic factors: a review. Aquat Sci. 73, 114.

Bul'ion, V.V. 1993, Primary production and trophic classification of water bodies. Methodological issues of studying primary production of plankton in inland waters. Gidrometeoizdat, SPb., 147-157.

Chekryzheva, T.A., Kalinkina, N.M., 2016, The structure and seasonal dynamics of phytoplankton communities in the open and closed littoral of Lake Onega (Pinguba, Puhtinskaya Bay). Proceedings of the Karelian Research Center of the Russian Academy of Sciences. Biology. 12: 83-95. 
International Journal of Ecology \& Development. 2020. Vol. 35(3).

Datsenko, Yu.S., Puklakov, V.V., Edelshtein, K.K., Grechushnikova, M.G., Erina, O.N., Sokolov, D.I., 2017, Model studies of hydrological factors of variability of the ecological status and water quality of stratified reservoirs. Water resources: new challenges and solutions. Lick, Novocherkassk, 334-340.

Dawidowicz, P., Prejs, A., Engelmayer, A Martyniak, A., Kozłowski, J., Kufel, L., Paradowska, M., 2002, Hypolimnetic anoxia hampers top-down foodweb manipulation in a eutrophic lake. Freshwater Biol. 47(12), 2401-2409.

Devyatkin, V.G., Meteleva, N.Yu., Vaynovsky, P.A. 2012, About the role of phytoplankton in the formation of the oxygen regime of the reservoir due to climatic variations. Water: chemistry and ecology. 12(54), 6874.

Dudakova, D.S., Rodionova, N.V., Protopopova, E.V., Kapustina, L.L., Bardinsky, D.S., 2015, The composition and dynamics of hydrobionts of the littoral zone of the Petrokrepost Bay of Ladoga Lake. Proceedings of KarRC of RAS. 2, 53-70.

Gorbunov, M.Yu., 2007, Vertical stratification of water masses in small lakes of the forest-steppe Volga region. Proceedings of the Samara Scientific Center of the Russian Academy of Sciences. 9(4), 973.

GOST 17.1.4.02-90. 2017, Interstate standard. The method of spectrophotometric determination of chlorophyll a. Standards publishing house, Moscow.

Hill, N.M., Keddy, P.A., Wisheu, I.C., 1998, A hydrological model for predicting the effects of dams on the shoreline vegetation of lakes and reservoirs. Environ Manage. 22: 723-736.

Ivano-Arakhley Lakes at the turn of the century: state and dynamics, 2013, Publishing House of the SB RAS, Novosibirsk, $337 \mathrm{p}$.

Izmestieva, L.R., Kozhova, O.M., Usenko, N.B., 1990, Photosynthetic pigments as a component of Baikal monitoring. Water resources. 3, 89-95.

Kasperovichene, Yu., Karosen, Yu., 2005, Structural and functional characteristics of the epiphyton and phytoplankton of the littoral zone of the lake. First (Lithuania). Bulletin of ZSU. 5, 70-77.

Katanskaya, V.M., 1981, Higher aquatic vegetation of USSR continental reservoirs. Methods of study. Leningrad, $187 \mathrm{p}$.

Khaliullina, L.Yu., Yakovlev, V.A., 2015, Phytoplankton of shallow waters in the upper reaches of the Kuibyshev reservoir. Publishing House of the Academy of Sciences of the Republic of Tatarstan, Kazan, $171 \mathrm{p}$.

Koch, E.W., 2001, Beyond light: physical, geological, and geochemical parameters as possible submersed aquatic vegetation habitat requirements. Estuaries. 24, 1-17.

Kowalczewski, A., Ozimek, T., 1993, Further long-term changes in the submerged macrophyte vegetation of the eutrophic Lake Mikolajskie (North Poland). Aquatic Botany. 46: 341-345.

Kozhova, O.M., 1970, Formation of phytoplankton. Formation of natural conditions and life of the Bratsk reservoir. Nauka, Moscow, 27-160.

Ladoga Lake - criteria for the state of the ecosystem, 1992, Science, SPb., $328 \mathrm{p}$.

Lambert, S.J., Davy, A.J., 2011, Water quality as a threat to aquatic plants: discriminating between the effects of nitrate, phosphate, boron and heavy metals on charophytes. New Phytologist. 189, 1051-1059.

Manual for the chemical analysis of surface water land, 1977, Gidrometeoizdat, Leningrad, 541 p.

Markager, S., Warwick, F.V., Tang, E.P.Y. 1999, Carbon fixation by phytoplankton in high Arctic lakes: Implications of low temperature for photosynthesis. Limnology and Oceanography. 44(3), 597-607.

Mineeva, N.M., 1995, Formation of the primary production of reservoirs of the Volga cascade in modern conditions. Phytoplankton Pigments. Water Resources. 22 (6), 746-756. 
International Journal of Ecology \& Development. 2020. Vol. 35(3).

Morozova, T.N., 1975, Seasonal and Annual Changes in Phytoplankton of Ivano-Arakhley Lakes: Author's Abstract. Dis. ... Cand. Biol. Sciences. Irkutsk, 29 p.

Morozova, T.N., 1981, Phytoplankton of Arakhley Lake. Biological productivity. Science, Novosibirsk, 1930.

Morozova, T.N., Shishkin, B.A., 1973, Annual changes in phytoplankton of some Ivano-Arakhley Lakes. Limnological studies in Transbaikalia. Chita, 57-70.

Moss, B., Beklioglu, M., Carvalho, L., Kilinc, S., Mcgowan, S., Stephen, D., 1997, Vertically-challenged limnology; contrasts between deep and shallow lakes. Hydrobiol. 342, 257-267.

Nagy, M.T., Marialigeti, K., Vegvari, P., Csepes, E., Bancsi, I., 2003, Stratification analysis of the Ohalasz Ox-bow of the River Tisza (Kiskore Reservoir, Hungary). Hydrobiol. 506 (1-3), 37-44.

Namsaraev, B.B., Barhutova, D.D., 2011, Soda Lakes of Southern Transbaikalia. Unique Ecosystems. Perm University Bulletin. 1, 55-59.

Obyazov, V.A., 2011, The hydrological regime of Transbaikalia lakes in a changing climate (using the example of Ivano-Arakhley Lakes). Water Management of Russia. 3, 4-14.

Obyazov, V.A., Usmanov, M.T., Zhilin, V.N., 2002, Hydrology. Ivano-Arakhley reserve: natural resource potential of the territory. Poisk, Chita, 21-27.

Odum, Y., 1975, Fundamentals of Ecology. Mir, Moscow, 84 p.

Ozimek, T., Kowalczewski, A., 1984, Long-term changes of the submerged macrophytes in eutrophic Lake Mikolajskie (North Poland). Aquatic Botany. 19, 1-11.

Padisak, J., Reynolds, C.S., 2003, Shallow lakes: the absolute, the relative, the functional and the pragmatic. Hydrobiol. 506 (1-3), 1-11.

Pomazkina, G.V., Belykh, O.I., Domysheva, V.M., Sakirko, M.V., Gnatovsky, R.Yu., 2010, Structure and Dynamics of Phytoplankton in Southern Baikal (Russia). Algology. 20 (1), 56-72.

Raspopov, I.M., Adams, L., Husák, Š., 2002, Influence of aquatic macrophytes on the littoral zone habitats of the Lake Ladoga, NW Russia. Preslia. 74, 315-321.

Riis, T., Hawes, I., 2002, Relationships between water level fluctuations and vegetation diversity in shallow water of New Zealand lakes. Aquat Bot. 74, 133-148.

Rip, W.J., Ouboter, M.R.L., Los, H.J., 2007, Impact of climatic fluctuations on Characeae biomass in a shallow, restored lake in the Netherlands. Hydrobiology. 584 (1), 415-424.

Rodrigo, M.A., Miracle, M.R., Vicente E., 2001, The meromictic Lake La Cruz (Central Spain). Patterns of stratification. Aquat. Sci. 63, 406-416.

Rusanovskaya, O.O., Kobanova, G.I., Shimaraeva, S.V., Pislegina, E.V., Krashchuk, L.S., Zilov, E.A., 2017, Water quality assessment of the Middle and Northern Baikal as a condition of coastal phytoplankton. XXI century. Technosphere safety. 2 (2), 30-37.

Sadchikov, A.P., 2003, Methods of studying freshwater phytoplankton. University and School, Moscow, $157 \mathrm{p}$.

Sand-Jensen, K., Borum, J., 1991, Interactions among phytoplankton, periphyton, and macrophytes in temperate freshwaters and estuaries. Aquat Bot. 41, 137-175.

Scheffer, M., Van, E.H., 2007, Shallow lakes theory revisited: various alternative regimes driven by climate, nutrients, depth and lake size. Hydrobiology. 584 (1), 455-466.

Shipunov, A.B., Baldin, E.M., Volkova, P.A., Korobeynikov, A.I., Nazarova, S.A., Petrov, S.V., Sufianov, V.G., 2014, Visual statistics, we use R. DMK Press, Moscow, 298 p. 
International Journal of Ecology \& Development. 2020. Vol. 35(3).

Shishkin, B.A., 1972, On the basic patterns of interannual changes in the regime of Ivano-Arakhley Lakes. Proceedings Zab. Phil. Geogr. Society of the USSR. 80: 151-162.

Shishkin, B.A., 1973, Seasonal and annual variations in biological regime of lakes in an ultracontinental climate (Trans-Baikal Region of U.S.S.R). Hydrobiology. 43 (1-2), 253-261.

Sigareva, L.E., 1993, Pigment criteria for assessing the ecological status of water bodies. Biological bases of environmental regulation. Science, Moscow, 64-69.

Tashlykova, N.A., 2018, Composition and structure of phytoplankton in the coastal and central parts of Arakhley Lake (Zabaikalsky territory) in spring and summer. Principy ekologii. 7 (3), 31-47.

Tashlykova, N.A., 2009, Ecological Features of the Development of Phytoplankton in the Delta Channels of the Selenga River and Sora Cherkalovo (Lake Baikal): Dis. ... Cand. Biol. Sciences. Ulan-Ude. 207 p.

Trifonova, I.S., 1990, Ecology and succession of lake phytoplankton. Science, Leningrad, 182 p.

Trifonova, I.S., Makartseva, E.S., 2006, Seasonal and long-term dynamics of phyto- and zooplankton and their interrelations in a mesotrophic lake. Biol. Internal Waters. 3, 18-25.

Usmanov, M.T., Zhilin, V.N., 2002, Characterization of hydrochemical parameters. Ivano-Arakhley reserve: natural resource potential of the territory, Search, Chita, 66-71.

Vinberg, G.G., Lyakhnovich, V.P., 1965, Fertilizer of Water. Food industry, Moscow, 270 p.

Vislyanskaya, I.G., 1982, Phytoplankton. Limnological studies on the Gulf of Onega Lake, Lake Onego. Science, Leningrad, 70-81.

Zamana, L.V., Borzenko, S.V., 2010, Hydrochemical regime of Salt Lakes in the south-eastern Transbaikalia. Geography and natural resources. 4, 100-107.

Zarubina, E.Yu., Yanygina, L.V., Burmistrova, Sh.S., Mitrofanova, E.Yu., Kim, G.V., Kotovshchikov, A.V., Krylova, E.N., Koveshnikov, M.I., 2005, Littoral biocenoses as one of the factors of ecosystem sustainability of Lake Teletskoye. Polzunovsky Bulletin. 4, 201-207.

Zhu, B, Fitzgerald, D.G, Mayer, G.M, Rudstam, L.G, Mill, E.L., 2006, Alteration of Ecosystem Function by Zebra Mussels in Oneida Lake: Impacts on Submerged Macrophytes. Ecosystems. 9, 1017-1028. 